\title{
What Impact Have SARS-CoV-2/Covid-19 Pandemic on the Reproductive and Child Health Programme of Uttar Pradesh in India over the 3 months after nationwide Lockdown announcement in March 2020 -A brief analysis
}

\section{Research Article}

Keywords:

Posted Date: March 29th, 2021

DOI: https://doi.org/10.21203/rs.3.rs-350287/v2

License: (c) (i) This work is licensed under a Creative Commons Attribution 4.0 International License. Read Full License 


\section{Abstract}

The authors have requested that this preprint be withdrawn due to erroneous posting.

\section{Full Text}

The authors have withdrawn this preprint from Research Square. 